\title{
A Review: Antioxidant and Immunomodulator Effects of Black Garlic
}

\author{
Kwartika Oktari, Zikra Azizah*, Boy Chandra, Ridho Asra
}

\section{School of Pharmaceutical Science (STIFARM) Padang, 25147 Indonesia}

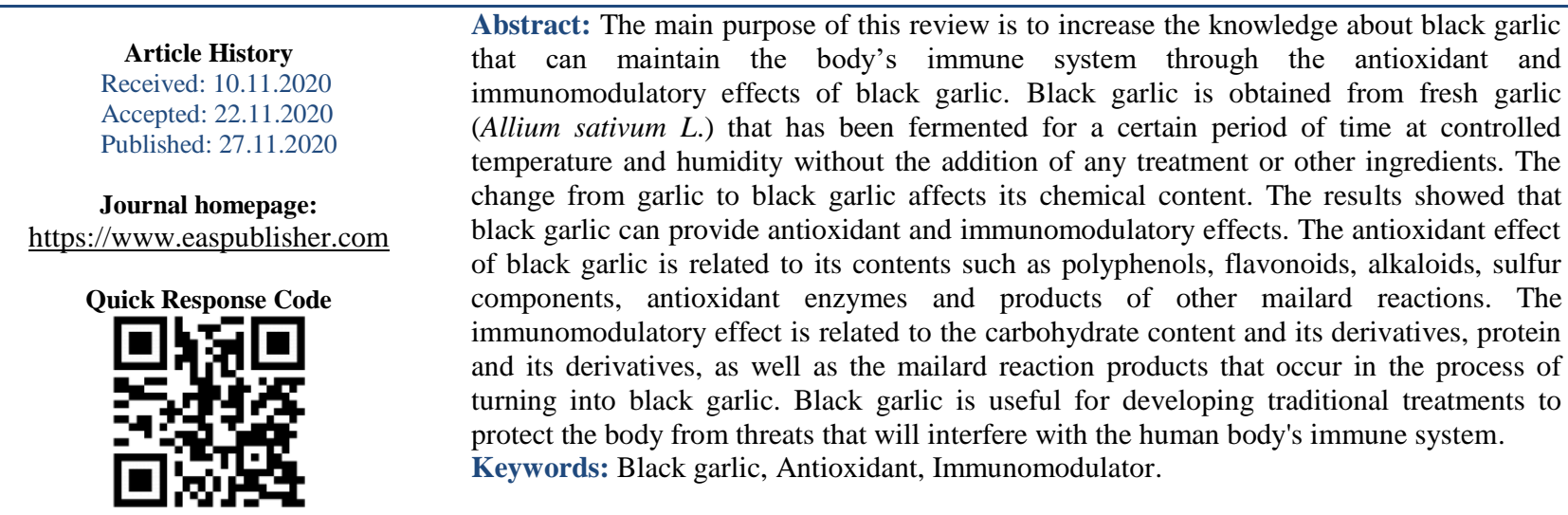

Copyright () 2020 The Author(s): This is an open-access article distributed under the terms of the Creative Commons Attribution 4.0 International License (CC BY-NC 4.0) which permits unrestricted use, distribution, and reproduction in any medium for non-commercial use provided the original author and source are credited.

\section{INTRODUCTION}

The human body is vulnerable to various threats that disrupt the body's immune system. Disorders of the human body's immune system can be caused by bacteria [1], viruses [2], as well as emotional or physiological stress that can cause various diseases [3]. Maintaining and modulating the body's immune system is one of the factors that can defend the body from invading pathogens [4].

The increasing awareness of the importance of maintaining the body's immunue system is being pushed up by increasing research in finding sources of substances that can maintain the body's immune system [4]. Natural ingredients have long been used to maintain the body's immune system, especially those with antioxidant and immunomodulatory properties. The plant reported to have antioxidant and immunomodulatory properties is garlic [5].

Garlic is a plant that belongs to the Allium family and the Amaryllidaceae family. The scientific name of garlic is Allium sativum L.. Garlic is a seasonal herbaceous plant, with a height of $30-60 \mathrm{~cm}$. It has a pseudo-stem, green, upright, round, on the inside of the soil a bulb is formed that ends with roots, some are formed above the ground. Single leaf, lanceolate leaf shape, flat linear leaf blade, flat edge, pointed tip, green,
1-2.5 $\mathrm{cm}$ wide, $30-60 \mathrm{~cm}$ long. The tuber is thick and fleshy to form the tuber layer [6].

In terms of taxonomy, garlic can be classified as follows [6]:

Division: Tracheophyta

$\begin{array}{ll}\text { Sub Division } & \text { : Spermatophytina } \\ \text { Class } & \text { : Magnoliopsida } \\ \text { Order } & \text { : Asparagales } \\ \text { Family } & \text { : Amaryllidaceae } \\ \text { Genus } & \text { : Allium } \\ \text { Species } & \text { : Allium } \\ \text { sativum L. }\end{array}$

\section{Foreign Names}

- English: garlic.

- French: ail.

- Bahasa Melayu: bawang putih

- Thai: krathiam (general), nom-tiam (northern)

- Philippines: bawang (Tagalog, Ilocano), ajos (Bisaya), ahus (Ibanag).

- Vietnamese: $\mathrm{t}$ [or] i

Garlic has many therapeutic benefits including antioxidant, immunomodulatory, anti-inflammatory and antiviral properties [5]. Efforts to increase the consumption of garlic, encourages creating ways that can increase the convenience of consuming garlic directly. Modifications made by fermentation of garlic produce black garlic. 
The picture of black garlic as shown below:

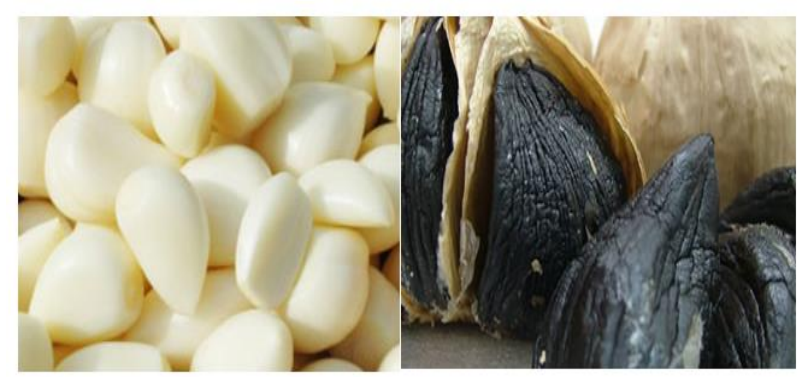

Fig-1: Garlic (left), changes into black garlic (right) [4]

Black garlic is obtained from fresh garlic (Allium sativum L.) that has been fermented for a certain period of time at a controlled high temperature, and under a controlled high humidity without the addition of other treatments or materials [4, 7]. When compared to fresh garlic, fermented black garlic does not release a strong aroma due to the reduced allicin content [7]. The fermentation process of black garlic undergoes degradation in the polysaccharide cell walls causing softening of the tissue, so that the texture of the black garlic is like gum. The process of changing from garlic to black garlic resulted in an increase or decrease in the components contained in black garlic [8].

Black garlic has several nutritious substances that provide a lot of therapeutic potential. The many benefits of black garlic include the potential as antioxidants [9] and immunomodulators [4] which can protect and maintain the body. Black garlic shows a therapeutic enhancement which is attributed to several ingredients in it [1].

\section{Data Collection}

The compiling of this review article used literature studies by determining sources or literature in the form of primary data or in the form of official books and national journals or international journals in the last 10 years (2010-2020). In making this review, data searches were also carried out using online media with the keywords as follows: black garlic, antioxidants, and immunomodulators. Search for the main references used in the production of this review article was done through trusted sources such as Mendeley, Science Direct, NCBI, Scopus, Web of Science, ResearchGate, Google Schoolar and other trusted journal publishers.

\section{DISCUSSION}

\section{Phytochemistry}

During the change from garlic to black garlic, there are several changes in the components contained in the garlic. The components contained in black garlic such as protein content $(14,326 \mathrm{~g} / 100 \mathrm{~g})$, total sugar in black garlic $420,893 \mathrm{mg} / \mathrm{g}$ [10]. The carbohydrate content of black garlic is associated with the sweet taste of black garlic [10]. Black garlic contains secondary metabolites which include flavonoids, alkaloids, [9], phenolic [1]. Black garlic also contains minerals in the form of potassium $(6,049 \mathrm{mg} / 100 \mathrm{~g})$, sulfur $(1,138 \mathrm{mg} /$ $100 \mathrm{~g})$, magnesium $(276.47 \mathrm{mg} / 100 \mathrm{~g})$, sodium $(246.34$ $\mathrm{mg} / 100 \mathrm{~g})$, calcium $(103,91 \mathrm{mg} / 100 \mathrm{~g})$ [11]. Black garlic contains organosulfur components such as $S$ allylcysteine (SAC), S-allylmercaptocysteine (SAMC), S-1-propenylcystein (S1PC), a water-soluble component [12] and Diallyl sul $f i$ de (DAS), Diallyl disul $f i d e$ (DADS), Diallyl trisul $f i$ de (DATS) a fat soluble component [13].

\section{Antioxidants In Black Garlic}

Black garlic is believed to protect the body from free radicals. An imbalance between antioxidant levels and free radicals can lead to various diseases [14]. Black garlic is reported to have a higher antioxidant content compared to garlic [1]. The antioxidant effect of black garlic is related to the bioactive compound content in it [9].

\section{Antioxidant Activity}

Free radicals are a form of reactive oxygen compounds that have unpaired electrons. Free radicals are often termed Reactive Oxygen Species (ROS). ROS include hydroxyl radical $\left.{ }^{\circ} \mathrm{OH}\right)$, superoxide radical $\left(\mathrm{O} 2^{\circ}\right.$ ) singlet oxygen $\left.{ }^{(1} \mathrm{O}_{2}\right)$ and hydrogen peroxide $\left(\mathrm{H}_{2} \mathrm{O}_{2}\right)$ [14]. Hydrogen peroxide is a relatively non-radical form of oxygen compounds [1].

Reactive Oxygen Species (ROS) attacks various molecules such as DNA, RNA, proteins, lipids, cofactors in enzymes, interferes with and destroys normal cell metabolism. The impact of the formation of ROS can be prevented by antidote to ROS by antioxidants. Free radicals can be controlled and resisted by donating electrons from antioxidants [14].

The antioxidant effect of black garlic is reported to be related to its chemical content in the form of flavonoids, alkaloids [9] phenolic [1]. Flavonoids and phenolics have antioxidant effects because these compounds have a $\mathrm{OH}$ - group attached to an aromatic carbon ring that has the ability to donate hydrogen atoms, thus playing an important role in the level of antioxidant power [15].

Flavonoids can prevent damage caused by free radicals. Flavonoids stabilize ROS by reacting with the reactive component of free radicals, resulting in less reactive and stable radicals [16]. The flavonoid content tested with ethanol solvent showed a significant increase $(\mathrm{p}<0.05)$, the ethanol extract of black garlic contained $3.0117 \% \pm 0.1783$ flavonoids while the ethanol extract of garlic contained $2.5836 \% \pm 0.0982$ flavonoids [9]. This indicates that black garlic has a higher antioxidant effect than garlic. 
The phenolic present in black garlic also shows a higher antioxidant effect than fresh garlic. The ratio of antioxidants in garlic and black garlic was tested using various solvents, namely water, ethanol and chloroform. Phenolics with water solvents have a higher phenolic value than other solvents. If sorted, the highest total phenolic is found in black garlic with water solvent of $147.58 \mathrm{mg} \mathrm{GAE} / \mathrm{g}$, black garlic with ethanol as a solvent of $43.01 \mathrm{mg}$ GAE / g, then garlic with water solvent of $5.68 \mathrm{mg} \mathrm{GAE} \mathrm{/} \mathrm{G,} \mathrm{garlic} \mathrm{with} \mathrm{ethanol}$ solvent of $2.86 \mathrm{mg} \mathrm{GAE} \mathrm{/} \mathrm{g,} \mathrm{garlic} \mathrm{with} \mathrm{chloroform}$ solvent $10.27 \mathrm{mg}$ GAE / $\mathrm{g}$ and black garlic with chloroform solvent had a value of $10.19 \mathrm{mg}$ GAE / $\mathrm{g}$ [1].

Black garlic contains alkaloid components that provide antioxidant effects [17]. Alkaloids have also been reported to reduce 1,1-diphenyl-2-picrylhydrazyl (DPPH) significantly [18]. The alkaloid content in black garlic tested with ethanol solvent showed a number of $6.9658 \% \pm 1.5362$ while in garlic $5.4130 \% \pm 0.2357$ [9]. Black garlic also contain alkaloid isomers in the form of (1S,3S)-1-methyl-1,2,3,4-tetrahydro-bcarboline-3-carboxylic acid and (1R, 3S)-1-methyl 1,2,3,4 tetrahydro-b-carboline-3-carboxylic acid [17].

Tests on the ability to inhibit free radicals in the form of extraction with black garlic distilled water using the 1,1-diphenyl-2-picrylhydrazyl (DPPH) method, obtained a comparison that black garlic were $79.21 \%$ higher than fresh garlic that was only $20.89 \%$. These results indicate that black garlic is thought to have stronger antioxidant properties than garlic [1].

A comparison of free radical scavenging activities between black garlic and garlic can also be done using the 2,2'-azino-bis-3-ethylbenzothiazoline-6sulfonic acid (ABTS) method. Tests with the ABTS method showed that black garlic had free radical scavenging activity of $99.56 \%$ higher than garlic at $35.92 \%$ [1]. Testing with the ABTS method is better than the DPPH method because ABTS can measure hydrophilic and hydrophobic substances [19].

The change in color from garlic to black is caused by the Maillard reaction, which is known as a non-enzymatic browning reaction [8]. Maillard reactions occur because of the reaction between amino acids protein and reducing sugars. Amino acids on heating will break down, the part of the breakdown will react with carbohydrates to form a maillard reaction which gives an antioxidant effect [8]. The products and derivatives of the mailard reaction have antioxidant properties because they can donate hydrogen to free radicals which can prevent oxidation [20].

Products from maillard reactions such as 5Hydroxy methylfurfural (5-HMF) are produced in the fermentation process in the processing of various types of food and beverages. Garlic will turn black if the accumulation of 5-HMF has exceeded the limit (4 g kg$\left.{ }^{1}\right)$ [8]. The testing of the $5-\mathrm{HMF}$ value of the product from the mailard reaction at $75^{\circ} \mathrm{C}$ and $85 \%$ humidity for 8 days showed a 5-HMF value of $1397,813 \mu \mathrm{g} / \mathrm{g}$ that gives an antioxidant effect on black garlic [10]. Antioxidant effect can significantly inhibit the formation of reactive oxygen species [21].

Alliin reduction occurs because alliin undergoes modification into compounds that can increase antioxidant properties such as Diallyl disulphide (DADS), Diallyl trisulphide (DATS) [13]. Extraction of black garlic using ethyl acetate, then fermented at a temperature of $80^{\circ} \mathrm{C}$ with a humidity of $75 \%$, the optimal value at 1 month processing time showed an increase in antioxidant effect accompanied by an increase in DADS and DATS values. Diallyl disulphide (DADS) was $74.9 \mathrm{mg} / \mathrm{mL}$, Diallyl trisulphide (DATS) was $79.7 \mathrm{mg} / \mathrm{mL}$ and an IC50 value was $28.8 \mathrm{mg} / \mathrm{mL}$ [13].

Black garlic contains organosulfur components which provide antioxidant properties. During the heating process there are sulfur components such as $\mathrm{S}$ allyl cysteine (SAC) [22]. Fermented black garlic at $70 \%$ humidity and temperatures that vary $(40,55,70, \&$ $85^{\circ} \mathrm{C}$ ) for 45 days showed that heating at low temperatures has a high level of SAC. The highest SAC value at a temperature of $40-45^{\circ} \mathrm{C}$ was $124.67 \mu \mathrm{g} / \mathrm{g}$ [22].

There are organic acids in black garlic, one of which is lactic acid [17]. The presence of lactic acid in black garlic gives a distinctive taste to black garlic. Apart from that, lactic acid which is the main organic acid of black garlic is also a strong antioxidant which affects the level of antioxidant power in black garlic [17].

Black garlic contains adenosine and uridine. Uridine can provide a good antioxidant enhancing effect on the body. The combination of uridine and inosine can increase myocardial metabolism, accelerate the biosynthesis of protein and nucleic acids and increase energy, and increase the metabolism of brain cells [23].

Black garlic also has a positive impact on relieving emotional or physiological stress that can cause various diseases. Stress can disrupt the body's immune system and suppress the production of antioxidant enzymes. Experiments carried out on mice under stress, the mice were then given black garlic (500 $\mathrm{mg} / \mathrm{kg}$, p.o) which gave the effect of reducing hormones associated with stress, such as the corticosterone release factor by $43.2 \%$ and increased levels of serotonin, dopamine by 2.09-2.11 fold. Reducing the production of ROS and increasing the activity of antioxidant enzymes such as superoxide dismutase (SOD), catalase, glutathione peroxidase in 
black garlic can alleviate disturbances from physiological stress [3].

\section{Immunomodulators In Black Garlic}

The body's immnue system can be enhanced with ingredients that contain immunomodulatory properties that can optimize the body's immune system. One of the immunomodulatory ingredients is black garlic [24]. Immunomodulatory properties can be seen from the body's biological ability to modulate the body into optimal conditions [25].

\section{Immunomodulatory Activity}

The main role of plant-sourced compounds providing immunomodulatory effects has emerged recently [24]. The discovery of new plant compounds with immune system modulation activity has become an increasingly important area of research for the maintenance of human health [4]. Black garlic is one of the ingredients that has an immunomodulatory effect [24].

The immunomodulatory properties exhibited by black garlic by modulating the cells associated with the immune system. Cells that are modulated in the form of cells associated with the body's immune system are magrophages, lymphocytes, natural killer (NK) cells and eucinophils and modulate cytokine secretion, immunoglobulin production, phagocytosis and magrophage activity $[4,24,25]$. The proper functioning of the immune system will optimize its function [4].

The change of garlic to black garlic causes an increase or decrease in some of the components contained in black garlic. The immunomodulatory effect of black garlic is related to the ingredients contained in it. The compounds contained in black garlic can inhibit and prevent the attack of pathogens [4].

Experiments using black garlic fermented at a temperature of $65-80^{\circ} \mathrm{C}$ and $70-80 \%$ humidity with white mice reported that black garlic have immunomodulatory and antitumor functions [4]. Black garlic showed anti-tumor activity by testing using a lymph cell culture system from mice treated with black garlic with a 50\% cure rate from BALB / C fibrosarcoma mice. Black garlic water extract can increase immunity by increasing the activity of Natural Killer (NK) cells which act as natural killers of foreign substances that attack the body which are considered to play an important role in eradicating tumor cells in vivo, and can encourage the human body to produce a strong immune response from the helper $\mathrm{T} 1$ (TH1) cells [4].

The polysaccharides in garlic include fructan and galactan. Fructant activity was assessed by immunostimulatory activity associated with lymphocytes and macrophages. The fructan content showed good antioxidant activity in black garlic. The fructan component in black garlic can decrease the production of Nitric Oxide (NO) by activating macrophage action. Fructan is easy to isolate from black garlic because it has water-soluble properties, this is an added value in a variety of pharmaceutical developments [26], it is also a substrate that can stimulate the growth of probiotic bacteria, which provides health benefits for the body as an antioxidant and immunomodulator. Research showed that prebiotics from oligosaccharides directly counter oxidative stress caused by an imbalance of Reactive Oxygen Species (ROS) [14], suggesting that black garlic exhibit antioxidant activity [23].

Black garlic contain N-a- (1-deoxy-D-fructos1-yl)arginine-L-(FruArg) as the main active component of black garlic. FruArg is a substance that belongs to the fructosamine class, from the non-enzymatic reaction between glucose and arginine. FruArg works can significantly inhibit the production of nitric oxide (NO) and modulate oxidative stress by regulating several proteins associated with oxidative stress [27].

Black garlic contains $14 \mathrm{kDa}$ protein, which is one of the main proteins of garlic. The effect of $14 \mathrm{kDa}$ protein on the immune system can be analyzed in dendrite cells isolated in BALB /c mice. Isolation of $14 \mathrm{kDa}$ protein increases the expression of CD40 molecules in dendrite cells which function in activating macrophages in the immune system, which can help the body fight pathogens [28].

Black garlic also contains glutahion (GSH) which can maintain the immune system and also acts as an antioxidant, glutathione is a protein tripeptide consisting of three main amino acids (glutamic, cysteine, and glycine). Glutathione protects the immune system by optimizing the function of lymphocytes and other immune cells. In human clinical studies, in HIVinfected patients, GSH and cysteine levels are decreased, which indicates a decreased immune system. Supplementation with glutathione can improve the condition in HIV patients [2, 29].

Disorders of the body's immune system caused by continuous oxidative stress can trigger genetic changes that can have the impact of converting normal cells into tumor cells. Black garlic is reported to inhibit the growth of cancer cells. The experiment used mice that had previously been induced by the experimental tumor model WEHI-164, they were then given an extract containing $0.4 \mathrm{~g}$ of black garlic per $\mathrm{mL}$ then diluted with distilled water which $100 \mathrm{mg} / \mathrm{kg}$ was administered intraperitoneally to the mice. The results showed that black garlic could slow down tumors and increase survival by $60.6 \%$. The immune response has been elevated by increasing CD $4+, \mathrm{CD} 8+\mathrm{T}$ cells and secretion of gamma-interferon, (IFN- $\gamma$ ) and Interleukin- 
4, which play a role in activating lymphocytes to increase antitumor effects [24].

Black garlic also contains sulfur components such as $S$-1-propenylcysteine (S1PC), $S$-allylcysteine (SAC) and $S$-allylmercaptocysteine (SAMC). The activity of the sulfur component of black garlic was shown in tests carried out on male Wistar rats, where the tails were cold induced using cold water $\left(15^{\circ} \mathrm{C}\right)$ for 10 minutes. Then given black garlic ethanol extract $(2 \mathrm{~g}$ / kg BW), S-1-propenylcysteine (S1PC) single dose (6.5 $\mathrm{mg} / \mathrm{kg} \mathrm{BW}$ ) and distilled water as a control. The test results showed that black garlic can reduce the decrease in blood flow in rats by $53 \%$ after 1 hour and close to the start after three hours, while administration of $S$-1propenylcysteine (S1PC) can reduce the decrease in blood flow in rats within 1 hour and increase nitrogen oxide plasma concentration (NOx). In addition, neither black garlic nor $S$-1-propenylcysteine (S1PC) affected the blood flow of cold-induced rats. Black garlic can modulate the body into normalcy [12].

\section{CONCLUSION}

Black garlic can have a good impact on the health of the body, especially to protect the body from threats that will interfere with the body's immune system. Black garlic has antioxidant and immunomodulatory effects that are obtained from the substances contained in them during the process of turning into black garlic. Black garlic can be a useful ingredient for developing traditional treatments to protect the body from threats that will interfere with the human body's immune system.

\section{REFERENCES}

1. Jang, H. J, Lee, H. J., Yoon, D. K., Ji, D. S., Kim, J. H., \& Lee, C. H. (2018). Antioxidant and antimicrobial activities of fresh garlic and aged garlic by-products extracted with different solvents. Food science and biotechnology, 27(1), 219-225.

2. Coco-Bassey, S, B., Asemota, E. A., Okoroiwu, H. U., Etura, J. E., Efiong, E. E., Inyang, I. J., \& Uko, E. K. (2019). Glutathione, glutathione peroxides and some hematological parameters of HIVseropositive subjects attending clinic in University of Calabar Teaching Hospital, Calabar, Nigeria. BMC Infectious Diseases. 19(1), 944.

3. Hwang, K. A., Hwang, Y. J., Hwang, I. G., Song, J., \& Kim, Y. J. (2019). Low temperature-aged garlic extract suppresses psychological stress by modulation of stress hormones and oxidative stress response in brain. Journal of Chinese Medical Association, 82(3), 191-195.

4. Wang, D., Feng, Y., Liu J, Yan J., Wang, M., Sasaki, J. I., \& Lu, C. (2010). Black garlic extracts enhance the immune system. Medicinal and
Aromatic Plant Science and Biotechnology, 4(1), 37-40.

5. Singh, R., \& Singh, K. (2019). Garlic: A spice with wide medicinal actions. Journal of Pharmacognosy and Phytochemistry, 8(1), 13491355.

6. Badan Pengawas Obat Dan Makanan. (2016). Serial The Power of Obat Asli Indonesi: Bawang Putih (Allium sativum L.). Jakarta: Badan Pengawas Obat dan Makanan.

7. Zhang, Z., Lei, M., Liu, R., Gao, Y., Xu, M., \& Zhang, M. (2015). Evaluation of alliin, Saccharide contents and antioxidant activities of black garlic during thermal processing. Journal of Food Biochemistry, 39(1), 39-47.

8. Zhang, X., Li, N., Lu, X., Liu, P., \& Qiao, X. (2016). Effect of temperature on the quality of black garlic. Journal of Science of Food Agric, 96(7), 2366-2372.

9. Azizah, Z., Yani, P., Yetti, R. D. (2020). Antioxidant activity ethanol extract of garlic (Allium sativum L.) and black garlic. International Journal of Research and Review, 7(9), 94-103.

10. Sun, Y. E., \& Wang, W. (2018). Changes in nutritional and bio-functional compounds and antioxidant capacity during black garlic processing. Journal of food scientists technology, 55(2), 479-488

11. Kang, O. J. (2016). Physicochemical characteristics of black garlic after different thermal processing steps. Preventive. Nutrition and food Science, 21(4), 348-354.

12. Ushijima, M., Kunimura, K., \& Suzuki, J. I. (2020). S-1-Propenylcysteine, a sulfur compound in aged garlic extract, alleviates cold-induced reduction in peripheral blood flow in rat via activation of the AMPK/eNOS/NO pathway. Experimental and Therapeutic Medicine, 20(3), 2815-2821.

13. Harmita, H., Suryadi, H., Syarif, M., \& Liksasa, L. D. (2020). Gas Chromatography Analysis of Diallyl Disulphide and Diallyl Trisulphide and Antioxidant Activity in Black Garlic. International Journal of Pharmaceutical Investigation, 10(1), 17-23.

14. Van den Ende, W., Peshev, D., \& De Gara, L. (2011). Disease prevention by natural antioxidant and prebiotics acting as ROS scavengers in the gastrointetinal tract. Trends in Food Science \& Technology, 22(12), 689-697.

15. Prasonto, D., Riyanti, E., \& Gartika, M. (2017). Uji aktivitas antioksidan ekstrak bawang putih (Allium sativum L). ODONTO: Dental Journal, 4(2), 122-128.

16. Panche, A. N., Diwan, A. D., \& Chandra, S. R. (2016). Flavonoids: an overview. Journal of nutrition science, 5 .

17. Lu, X., Li, N., Qiao, X., Qiu, Z., \& Liu, P. (2017). Composition analysis and antioxidant properties of 
black garlic extract. Journal of food and drug analysis, 25(2), 340-349.

18. Tiong, S. H., Looi, C. Y., Hazni. H., Arya, A., Payda, M., Wong, W. F., Cheah, S. H., Mustafa, M. R., \& Awang, K. (2013). Antidiabetic and antioxidant properties of alkaoids from Cantharanthus roseus (L.) G. Don. Molecules, 18(8), 9770-9784.

19. Martysiak-Zurowska, D., \& Wenta, W. (2012). A comparison of ABTS and DPPH methods for assessing the total antioxidant capacity of human milk. Acta Scientiarum Polonorum Technologia. Alimentaria, 11(1), 83-89.

20. Wakamatsu, J., Strak, T. D., \& Hofmann, T. (2019). Antioxidative mailard reaction products generated in processed aged garlic extract. Journal of agritural and food chemistry , 67(8), 21902200.

21. Kim, H. K., Choi, Y. W., Lee E. N., Park, J. K., Kim, S. G., Park, D. J., Kim, B. S., Lim Y. T., \& Yoon, S. (2011). 5-Hydroxymethylfurfural from black garlic extract prevents TNF-a-induced monocytic cell adhesion to HUVECs by suppression of vascular cell adhesion molecule-1 expression, reactive oxygen species generation and NF-kb activation. Phytotherapy Research, 25 (7), 965-974.

22. Bae, S. E., Cho, S. Y., Won, Y. D., Lee, S. H., \& Park, H. J. (2014). Changes in S-allyl cysteine contents and physicochemical properties of black garlic during heat treatment. LWT - Food Science and Technology, 55 (1), 397- 402.

23. Li, M., Yan, Y. X., Yu, Q. T., Deng, Y., Wu, D. T., Wang, Y., Ge, Y. Z.; Li, S. P., \& Zhao, J. (2017). Comparison of immunomodulatory effects of fresh garlic and black garlic polysaccharides on raw 264.7 macrophages. Jornal of food science. 8 (3), 765-771.

24. Fallah-Rostami, F., Tabari, M. A., Esfandiari, B., Aghajanzadeh, H., \& Behzadi, M. Y. (2013).
Immunomodulatory activity of aged garlic extract against implanted fibrosarcoma tumor in mice. North American journal of medical sciences, 5 (3), 207.

25. Tsai, C. C., Lin, C. R., Tsai, H. Y., Chen, C. J., Li, W. T., Yu, H. M., Ke, Y. Y., Hsei, W. Y., Chang, C. Y., Wu, C. Y., Chen, S. T., \& Wong, C. H. (2013). The immunologically active oligosaccharides isolated from wheatgrass modulate monocytes via toll-like receptor-2 signaling. The Journal of Biological Chemistry, 288(24), 17689-17697.

26. Chandrashekar, P. M., Prashanth, K. V. H., \& Venkatesh, Y. P. (2011). Isolation, structural elucidation and immunomodulatory activity of fructans from aged garlic extract. Phytochemistry, 72(2-3), 255-264.

27. Zhou, H., Qu, Z., Mossine, V. V., Nknolise, D. L., Li, J., Chen, Z., Cheng, J., Greenlife, C. M., Mawhinney, T. P., Brown, P. N., Fritsche, K. L., Hannink, M., Lubahn, D. B., Sun, G. Y., \& Gu, Z. (2014). Proteomic analysis of the effects of aged garlic extract and its FruArg component on lipopolysaccharide-induced neuroinflammatory response in microglial cells. PLoS One, 9(11), e11351.

28. Ahmadabad, H. N., Hassan, Z. M., Saffari, E., Bozorgemehr, M., Ghanzafari, T., \& Moazzeeni, S. M. (2011) Evaluation of the immunomodulatory effect of the $14 \mathrm{kDa}$ protein isolated from aged garlic extract on dendritic cells. Cellular immunology, 269(2), 90-95.

29. Watson, W. H., Ritzenthaler, J. D., Peyrani, P., Wiemken, T. L., Furmanek, S., Vega, A. M., Burke, T. J., Zheng, Y., Ramirez, J. A., \& Roman, J. (2019). Plasma cysteine/cystine and glutathione/glutathione disulfide redox potentials in HIV and COPD patients. Free Radical Biology and Medicine, 143, 55-61. 